\title{
Topical Betulinic Acid
}

National Cancer Institute

\section{Source}

National Cancer Institute. Topical Betulinic Acid. NCI Thesaurus. Code C78477.

A topical formulation of a pentacyclic lupane-type triterpene derivative of betulin (isolated from the bark of Betula alba, the common white birch) with antiinflammatory, anti-HIV and antineoplastic activities. Betulinic acid induces apoptosis through induction of changes in mitochondrial membrane potential, production of reactive oxygen species, and opening of mitochondrial permeability transition pores, resulting in the release of mitochondrial factors involved in apoptosis, activation of caspases, and DNA fragmentation. Although orig inally thought to exhibit specific cytotoxicity against melanoma cells, this agent has been found to be cytotoxic against non-melanoma tumor cell types including neuroectodermal and brain tumor cells. 